\title{
Synthesis, Characterization and Biological evaluation of some novel Pyrazolo [1,5-a]Pyrimidine derivatives
}

\author{
Nilesh M. Thumar*, Ankur A. Kaneria, Milan Vadodaria, Kartik Ladva* \\ Chemical Research Laboratory, Shree M. \& N. Virani Science College, Rajkot-360005, Gujarat \\ (India) \\ *E-mail: thumarnilesh@gmail.com \\ *E-mail: kdladva@vsc.edu.in
}

Keywords: Pyrazolo[1,5-a]pyrimidine, ketene dithioacetal, pyrazolopyrimidine, antimicrobial activity.

ABSTRACT: A convenient synthesis of substituted Pyrazolo[1,5-a]pyrimidine was carried out by the reaction of different ketene dithioacetals with different aromatic amine in isopropanol in the presence of potassium carbonate. The newly synthesized compound were characterized by ${ }^{1} \mathrm{H}$ NMR, IR, Mass and screened for their antimicrobial activity against various strains of bacteria and fungi. From the synthesized different NCEs, compounds $8 \mathrm{a}, 8 \mathrm{~d}$ and $8 \mathrm{e}$ are broad spectrum drug which can inhibit the growth of gram positive, gram negative bacteria and fungi.

\section{INTRODUCTION}

Functionalized nitrogen heterocycles play a prominent role in medicinal chemistry and therefore they have been intensively used as scaffolds for drug development [1]. Various heterocycles such as pyrazole, pyridine and pyrimidine have been used as key pharmacophores. Pyrazolo[1,5-a] pyrimidines have attracted considerable interest because of their biological activity. The heterocyclic fusion of pyrimidine ring and pyrazole ring resulted in formation of pyrazolopyrimidines, the structural analogues of biogenic purine class, undoubtedly, has high significance in the field of pharmaceutical and biotechnological sciences with wide spectrum of biological activities and its several derivatives [2-4]. Several compounds of this class display interesting antitrypanosomal [4] and antischistosomal activities [6]. They are used as HMG-CoA reductaseinhibitors [7], COX-2 selective inhibitors [8], 30,50-cyclic-AMP phosphodiesteraseinhibitors [9], CRF1 antagonists [10-11], selective peripheral benzodiazepine receptor ligands [12-16], potassium channel [17] and histamine-3 receptor ligands [18], CDK9 inhibitor [19] and antianxiety agents [20].

Some pyrazolopyrimidines serve as efficient sedative-hypnotic and anxiolytic drugs like zaleplon (Sonata, hypnotic) [21], indiplon (hypnotic) [22-24] and ocinaplon (anxiolytic)[25-26], fasiplon (anxiolytic). These drugs are related to the class of nonbenzodiazepines, and their therapeutic effect is due to allosteric enhancement of the action of the inhibitory neurotransmitter GABA at the GABAA receptor. These examples emphasize the importance of pyrazole-fused heterobiaryls, as well as pyrazolopyridines, as key pharmacophores in bioactive small molecules.

We have synthesize pyrazolo[1,5-a] pyrimidine derivatives by refluxing different ketene dithioacetals with aromatic amine in the presence of potassium carbonate in isopropanol.

The newly synthesized compounds were characterized by IR, Mass and ${ }^{1} \mathrm{H}$ NMR. All the synthesized compounds were evaluated for their antimicrobial activity. 


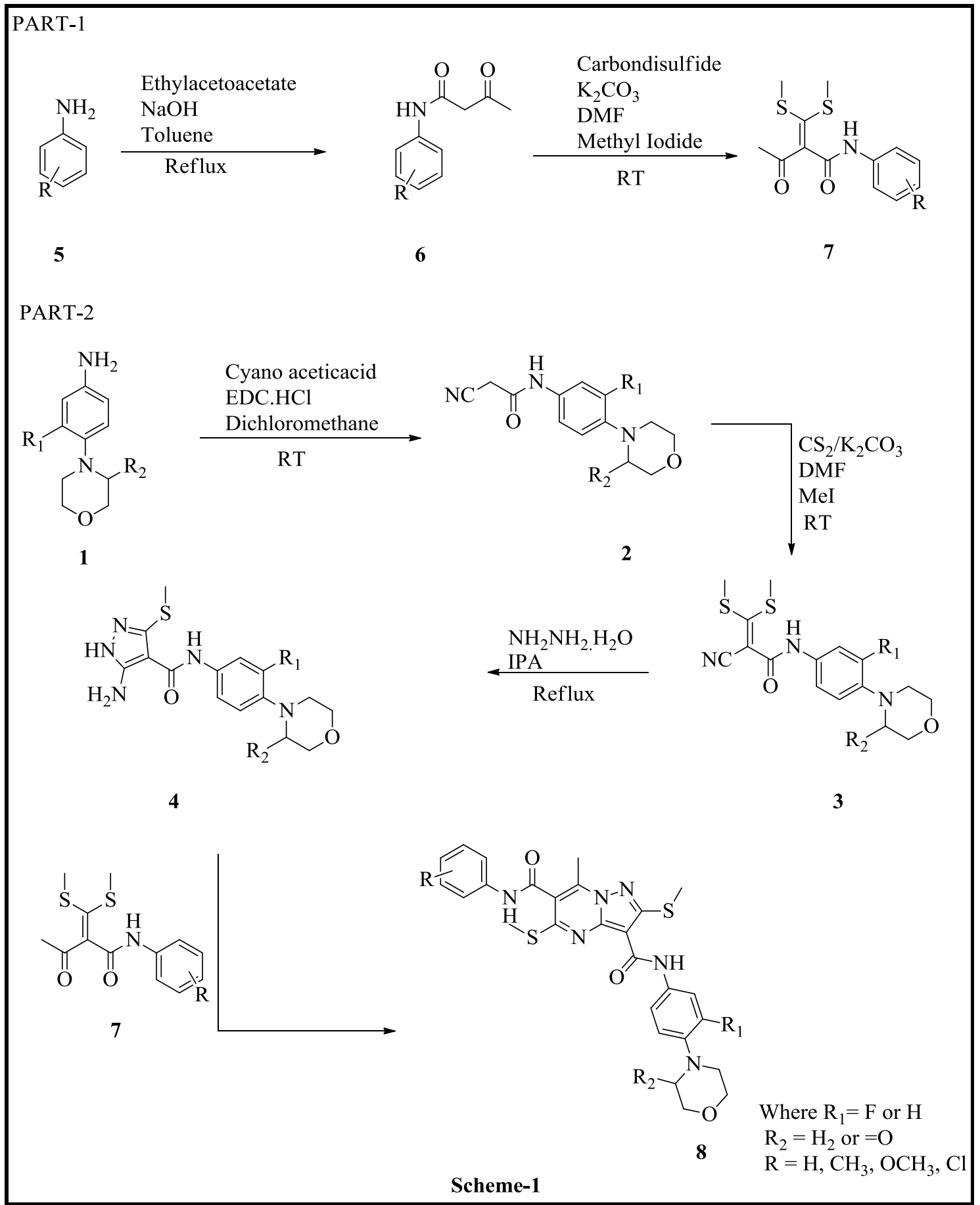

Scheme 1: Reaction Scheme for 8a-I

\section{EXPERIMENTAL}

All chemicals used were commercial supply and used without further purification. The progress of the reaction was monitored by analytical TLC on precoated plates (silica gel 60, F254) and visualized with UV light. Melting points were determined using open capillary tube and are uncorrected. NMR spectra $\left({ }^{1} \mathrm{H}\right.$ at $\left.400 \mathrm{MH}_{\mathrm{z}}\right)$ were recorded using DMSO-d ${ }^{6}$ as a solvent and chemical shifts are expressed in parts per million ( $\mathrm{ppm})$ related to internal standard TMS. Infrared spectra were determined on a Shimadzu FT-IR. The specifications of the LC/MS are as follows: electrospray $(+)$ ionization, mass range $100-800 \mathrm{Da}, 20-\mathrm{V}$ cone voltage, and Xterra MS $\mathrm{C}_{18}$ column $(2.1 \mathrm{~mm} \times 50 \mathrm{~mm} \times 3.5 \mu \mathrm{m})$. 


\section{General procedure for the Preparation of 2-Cyano-N-arylacetamide (2)}

To a stirred solution of different aromatic amine $(110 \mathrm{mmol}) \mathbf{1}$ and cyanoaceticacid (121 $\mathrm{mmol})$ in the presence of triethylamine $(165 \mathrm{mmol})$ in dichloromethane $(100 \mathrm{ml}), \mathrm{EDC} . \mathrm{HCl}(121$ mmol) was added lotwise at $0-10^{\circ} \mathrm{C}$ with 30 to 60 minutes. The reaction mixture was allowed to stir at room temperature for 2 to 3 hours. The progress of the reaction was monitored on TLC. After completion of the reaction water was added into the reaction mixture. The organic layer was separated and washed with water and dried over sodium sulphate. The solvent was distilled under vacuum to give 2-Cyano-N-arylacetamide $\mathbf{2}$ as a cream to brown color solid compound which was used for the next stage without purification (82-89\% yield).

\section{General procedure for the Preparation of 2-cyano-3,3-bis(methylthio)- $N$-arylacrylamide (3)}

To a stirred solution of 2-cyano-N-arylacetamide $(20 \mathrm{mmol}) 2$ in N,N-dimethylformamide $(25 \mathrm{ml})$, dry potassium carbonate $(20 \mathrm{mmol})$ was added at room temperature. The reaction mixture was stirred at room temperature for 2 hours. Carbon disulfide $(75 \mathrm{mmol})$ was added at room temperature and the reaction mixture was stirred for 2 hours. Then the reaction mixture was cooled to $0-10^{\circ} \mathrm{C}$ and methyl iodide $(50 \mathrm{mmol})$ was added in to the reaction mixture and the reaction mixture was stirred for 3 to 4 hours at room temperature. The progress of the reaction was monitored on TLC. After completion of the reaction, water was added into the reaction mixture and the reaction mixture was stirred for 1 hour at room temperature. The precipitated solid material was filtered, washed with water and dried to give 2-Cyano-3,3-bis(methylthio)-N-arylacrylamide 3 (75$88 \%$ yield) as a yellow solid.

\section{General procedure for the preparation of 5-amino-N-aryl-3-(methylthio)-1H-pyrazole-4- carboxamide (4)}

To a stirred solution of 2-Cyano-3,3-bis(methylthio)-N-arylacrylamide (20 mmol) $\mathbf{3}$ and hydrazine hydrate $(25 \mathrm{mmol})$ in isopropanol $(100 \mathrm{ml})$ was heated to reflux for 2 to 3 hours. The progress of the reaction was monitored by TLC. After completion of the reaction, the reaction mixture was cooled to room temperature. The reaction mixture was poured into crushed ice and stirred for 1 hour at room temperature. The precipitated solid material was filtered, washed with water and dried to give 5-amino-N-aryl-3-(methylthio)-1H-pyrazole-4-carboxamide 4 as a yellow color solid compound in 70-90\% yield.

\section{General procedure for the preparation of different Acetoacetanilide derivatives (6)}

To a stirred solution of different aromatic amine $(10 \mathrm{mmol}) \mathbf{5}$ and ethylacetoacetate (20 $\mathrm{mmol})$ in the presence of catalytic amount potassium hydroxide $(10 \%)$ in toluene $(100 \mathrm{ml})$ was heated at reflux temperature for 15 to 20 hours. The progress of the reaction was monitored by TLC. After completion of the reaction the solvent was removed under vacuum and methanol was added into the residue and stirred for 1 hour at room temperature. The precipitated solid material was filtered, washed with methanol and dried to give different acetoacetanilide compounds $\mathbf{6}$ as an off white to light yellow color solid compound in 35-45\% yield.

\section{General procedure for the preparation of different ketene dithioacetals (7)}

To a stirred solution of acetoacetanilide derivatives $(10 \mathrm{mmol}) \mathbf{6}$ in N,N-dimethylformamide $(10 \mathrm{ml})$, dry potassium carbonate $(11 \mathrm{mmol})$ was added at room temperature. The reaction mixture was stirred at room temperature for 2 hours. Carbon disulfide $(30 \mathrm{mmol})$ was added at room temperature and the reaction mixture was stirred for 2 hours. Then the reaction mixture was cooled to $0-10^{\circ} \mathrm{C}$ and methyl iodide $(25 \mathrm{mmol})$ was added in to the reaction mixture and the reaction mixture was stirred for 3 to 4 hours at room temperature. The progress of the reaction was monitored by TLC. After completion of the reaction, water was added into the reaction mixture and the reaction mixture was stirred for 1 hour at room temperature. The precipitated solid material was filtered, washed with water and dried to give ketene dithioacetals derivatives 7 as a yellow color solid in $70-80 \%$ yield. 


\section{General procedure for the preparation of fused pyrazolopyrimidines (8)}

To a stirred mixture of 5-amino-N-aryl-3-(methylthio)-1Hpyrazole-4-carboxamide (5 mmol) 4, ketene dithioacetals $(5 \mathrm{mmol}) 7$ potassium carbonate $(10 \mathrm{mmol})$ in $(10 \mathrm{ml})$ was heated to reflux temperature for 12 to 14 hours. The progress of the reaction was monitored by TLC. After completion of reaction the reaction mixture was cooled to room temperature and water was added. The reaction mixture was stirred for 1 hour at room temperature. The solid material was filtered, washed with water and dried to give fused pyrazolopyrimide derivatives. The compound was crystallized from methanol to give pure compound in $80-90 \%$ yield.

Table 1: Physical Data of Compound 8a-I

\begin{tabular}{|c|c|c|c|c|c|}
\hline $\begin{array}{c}\text { Compound } \\
\text { Code }\end{array}$ & $\mathbf{R}$ & $\mathbf{R}_{\mathbf{1}}$ & $\mathbf{R}_{\mathbf{2}}$ & $\mathbf{M . F}$ & Yield (\%) \\
\hline $8 \mathrm{a}$ & $\mathrm{H}$ & $\mathrm{H}$ & $\mathrm{O}$ & $\mathrm{C}_{27} \mathrm{H}_{26} \mathrm{~N}_{6} \mathrm{O}_{4} \mathrm{~S}_{2}$ & 85 \\
\hline $8 \mathrm{~b}$ & $4-\mathrm{CH}_{3}$ & $\mathrm{H}$ & $\mathrm{O}$ & $\mathrm{C}_{28} \mathrm{H}_{28} \mathrm{~N}_{6} \mathrm{O}_{4} \mathrm{~S}_{2}$ & 88 \\
\hline $8 \mathrm{c}$ & $4-\mathrm{OCH} \mathrm{H}_{3}$ & $\mathrm{H}$ & $\mathrm{O}$ & $\mathrm{C}_{28} \mathrm{H}_{28} \mathrm{~N}_{6} \mathrm{O}_{5} \mathrm{~S}_{2}$ & 83 \\
\hline $8 \mathrm{~d}$ & $4-\mathrm{Cl}$ & $\mathrm{H}$ & $\mathrm{O}$ & $\mathrm{C}_{27} \mathrm{H}_{25} \mathrm{ClN}_{6} \mathrm{O}_{4} \mathrm{~S}_{2}$ & 80 \\
\hline $8 \mathrm{e}$ & $\mathrm{H}$ & $\mathrm{H}$ & $\mathrm{H}_{2}$ & $\mathrm{C}_{27} \mathrm{H}_{28} \mathrm{~N}_{6} \mathrm{O}_{3} \mathrm{~S}_{2}$ & 82 \\
\hline $8 \mathrm{f}$ & $4-\mathrm{CH}_{3}$ & $\mathrm{H}$ & $\mathrm{H}_{2}$ & $\mathrm{C}_{28} \mathrm{H}_{30} \mathrm{~N}_{6} \mathrm{O}_{3} \mathrm{~S}_{2}$ & 90 \\
\hline $8 \mathrm{~g}$ & $4-\mathrm{OCH}$ & $\mathrm{H}$ & $\mathrm{H}_{2}$ & $\mathrm{C}_{28} \mathrm{H}_{30} \mathrm{~N}_{6} \mathrm{O}_{4} \mathrm{~S}_{2}$ & 84 \\
\hline $8 \mathrm{~h}$ & $4-\mathrm{Cl}$ & $\mathrm{H}$ & $\mathrm{H}_{2}$ & $\mathrm{C}_{27} \mathrm{H}_{27} \mathrm{ClN}_{6} \mathrm{O}_{3} \mathrm{~S}_{2}$ & 85 \\
\hline $8 \mathrm{i}$ & $\mathrm{H}$ & $\mathrm{F}$ & $\mathrm{H}_{2}$ & $\mathrm{C}_{27} \mathrm{H}_{27} \mathrm{FN}_{6} \mathrm{O}_{3} \mathrm{~S}_{2}$ & 87 \\
\hline $8 \mathrm{j}$ & $4-\mathrm{CH}$ & $\mathrm{F}$ & $\mathrm{H}_{2}$ & $\mathrm{C}_{28} \mathrm{H}_{29} \mathrm{FN}_{6} \mathrm{O}_{3} \mathrm{~S}_{2}$ & 90 \\
\hline $8 \mathrm{k}$ & $4-\mathrm{OCH}$ & $\mathrm{F}$ & $\mathrm{H}_{2}$ & $\mathrm{C}_{28} \mathrm{H}_{29} \mathrm{FN}_{6} \mathrm{O}_{4} \mathrm{~S}_{2}$ & 85 \\
\hline $8 \mathrm{l}$ & $4-\mathrm{Cl}$ & $\mathrm{F}$ & $\mathrm{H}_{2}$ & $\mathrm{C}_{27} \mathrm{H}_{26} \mathrm{ClFN}_{6} \mathrm{O}_{3} \mathrm{~S}_{2}$ & 80 \\
\hline
\end{tabular}

\section{1. Spectroscopic data for the Compounds:}

7-methyl-2,5-bis(methylthio)-N3-(4-morpholinophenyl)-N6-(p-tolyl)pyrazolo[1,5-a]pyrimidine -3,6-dicarboxamide (8f)

Yield: $90 \%$. Yellow solid; $\mathrm{mp}>300^{\circ} \mathrm{C}$; Rf 0.43 (9:1 DCM-Methanol); ${ }^{\mathbf{1}} \mathbf{H}$ NMR (400 MHz, DMSO-d $\left.^{6}\right): \delta=2.271(\mathrm{~s}, 3 \mathrm{H}), 2.788(\mathrm{~s}, 3 \mathrm{H}), 3.045-3.068(\mathrm{t}, 4 \mathrm{H}), 3.731-3.754(\mathrm{t}, 4 \mathrm{H}), 6.925-6.948$ $(\mathrm{d}, 2 \mathrm{H}), 7.114-7.136(\mathrm{~d}, 2 \mathrm{H}), 7.531-7.571(\mathrm{dd}, 4 \mathrm{H}), 10.617(\mathrm{~s}, 1 \mathrm{H}), 12.113(\mathrm{~s}, 1 \mathrm{H}) \mathrm{ppm} ; \mathrm{MS}: \mathrm{m} / \mathrm{z}$ $563.1(\mathrm{M}+1)^{+}$; IR (KBr) $\mathbf{C m}^{-1}:$ 3030.17, 2970.38, 1734.01, 1716.65, 1539.20, 1508.33, 1228.66, $1112.93,817.82$

N6-(4-chlorophenyl)-N3-(3-fluoro-4-morpholinophenyl)-7-methyl-2,5-bis(methylthio)pyrazolo [1,5-a]pyrimidine-3,6-dicarboxamide (81)

Yield: $80 \%$. Yellow solid; $\mathrm{mp}>300^{\circ} \mathrm{C}$; Rf 0.41 (9:1 DCM-Methanol); ${ }^{\mathbf{1}} \mathbf{H}$ NMR (400 MHz, DMSO-d $\left.^{6}\right): \delta=2.785(\mathrm{~s}, 3 \mathrm{H}), 2.951-2.972(\mathrm{t}, 4 \mathrm{H}), 3.709-3.753(\mathrm{t}, 4 \mathrm{H}), 7.006-7.052(\mathrm{t}, 1 \mathrm{H}), 7.206-$ $7.234(\mathrm{dd}, 1 \mathrm{H}), 7.358-7.380(\mathrm{dd}, 2 \mathrm{H}), 7.704-7.748(\mathrm{~m}, 3 \mathrm{H}), 10.784(\mathrm{~s}, 1 \mathrm{H}), 12.252(\mathrm{~s}, 1 \mathrm{H}) \mathrm{ppm}$; MS: $\mathrm{m} / \mathrm{z} 601.1(\mathrm{M}(35 \mathrm{Cl})+1)^{+}, \mathrm{m} / \mathrm{z} 603.0(\mathrm{M}(37 \mathrm{Cl})+1)^{+}$; IR (KBr) $\mathbf{C m}^{-1}: 3047.58,2970.38$, $1734.01,1716.65,1539.20,1508.33,1226.73,1111.00,813.96$

N3-(3-fluoro-4-morpholinophenyl)-N6-(4-methoxyphenyl)-7-methyl-2,5-bis pyrazolo[1,5-a]pyrimidine-3,6-dicarboxamide (8k)

Yield: $85 \%$. cream solid; $\mathrm{mp}>300^{\circ} \mathrm{C}$; Rf 0.49 (9:1 DCM-Methanol); ${ }^{1} \mathbf{H}$ NMR (400 MHz, DMSO-d $\left.^{6}\right): \delta=2.784(\mathrm{~s}, 3 \mathrm{H}), 2.950-2.972(\mathrm{t}, 4 \mathrm{H}), 3.709-3.739(\mathrm{~m}, 7 \mathrm{H}), 6.832-6.915(\mathrm{~d}, 2 \mathrm{H})$, 7.005-7.051 (t, 1H), 7.202-7.224 (d, 1H), 7.579-7.602 (d, 2H), 7.705-7.748 (dd, 1H), $10.812(\mathrm{~s}$, 1H), 11.967 (s, 1H) ppm; MS: m/z $596.2(\mathrm{M}+1)^{+}$; IR (KBr) $\mathbf{C m}^{-1}$ : 3030.17, 2929.87, 1734.01, $1716.65,1539.20,1521.84,1247.94,1111.00,810.10$ 
Table 2: Antibacterial activity of compound 8a-I

\begin{tabular}{|c|c|c|c|c|c|c|}
\hline \multirow[t]{2}{*}{ Compounds } & \multicolumn{4}{|c|}{ Antibacterial MIC $(\mu \mathrm{g} / \mathrm{mL})$} & \multicolumn{2}{|c|}{$\begin{array}{c}\text { Antifungal MIC } \\
(\mu \mathrm{g} / \mathrm{mL})\end{array}$} \\
\hline & $\begin{array}{c}B . \\
\text { megaterium } \\
\text { MTCC2444 }\end{array}$ & $\begin{array}{l}\text { S. aureus } \\
\text { MTCC737 }\end{array}$ & $\begin{array}{c}\text { E. coli } \\
\text { MTCC1687 }\end{array}$ & $\begin{array}{c}P . \\
\text { aeruginosa } \\
\text { MTCC3541 }\end{array}$ & $\begin{array}{c}\text { A. niger } \\
\text { MTCC282 }\end{array}$ & $\begin{array}{c}\text { A. flavus } \\
\text { MTCC418 }\end{array}$ \\
\hline Streptomycin & & & 50 & 50 & & \\
\hline Ampicillin & 100 & 100 & & & & \\
\hline Nystatin & & & & & 100 & 100 \\
\hline $8 \mathrm{a}$ & 500 & 500 & 500 & 125 & 125 & 500 \\
\hline $8 b$ & 1000 & 1000 & 1000 & 1000 & 1000 & 1000 \\
\hline $8 \mathrm{c}$ & 1000 & 1000 & 1000 & 1000 & 1000 & 1000 \\
\hline $8 \mathrm{~d}$ & 500 & 500 & 500 & 500 & 500 & 500 \\
\hline $8 \mathrm{e}$ & 500 & 500 & 500 & 500 & 250 & 250 \\
\hline $8 f$ & 500 & 500 & 500 & 500 & 1000 & 500 \\
\hline $8 \mathrm{~g}$ & 500 & 1000 & 250 & 500 & 500 & 500 \\
\hline $8 \mathrm{~h}$ & 500 & 500 & 500 & 1000 & 1000 & 500 \\
\hline $8 \mathrm{i}$ & 1000 & 500 & 500 & 1000 & 1000 & 1000 \\
\hline $8 \mathrm{j}$ & 1000 & 1000 & 1000 & 1000 & 1000 & 1000 \\
\hline $8 \mathrm{k}$ & 500 & 500 & 500 & 250 & 250 & 250 \\
\hline 81 & 1000 & 500 & 500 & 250 & 250 & 500 \\
\hline
\end{tabular}

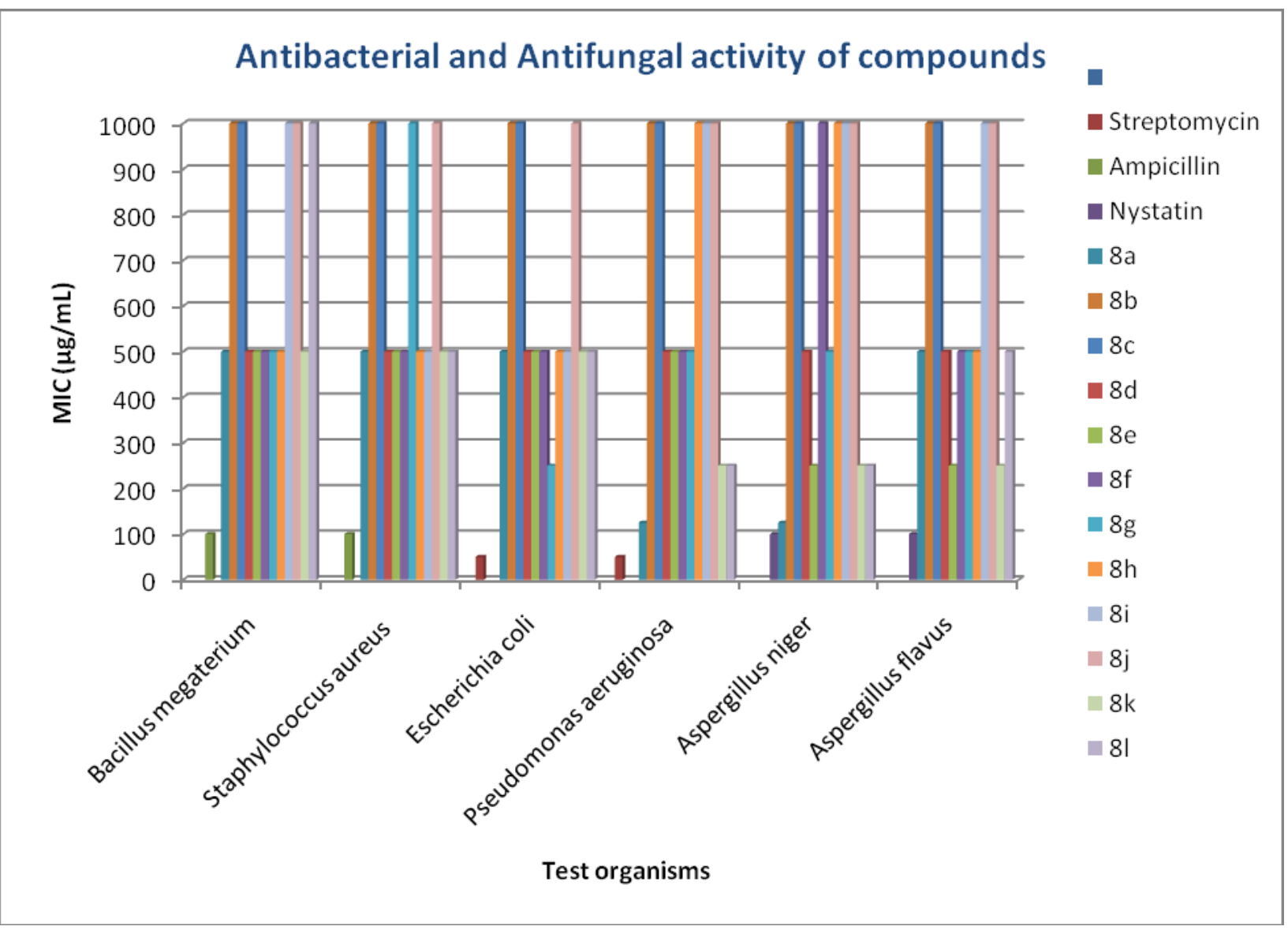

Fig. 1: Antibacterial activity chart of compound 8a-l 


\section{RESULT AND DISCUSSION}

Chemistry: The synthesis of 7-Methyl-2,5-bis(methylthio)- $\mathrm{N}^{3}, \mathrm{~N}^{6}$-diarylpyrazolo[1,5-a]pyrimidine3,6-dicarboxamide is outlined in scheme-1. Different aromatic amine is reacted with ethylacetoacetate in the presence of catalytic sodium hydroxide in toluene to give acetanilide derivatives, which is reacted with carbon disulfide the presence of base followed by methyl iodide in N,N-dimethyl formamide to give ketene dithioacetyl derivatives. Different aromatic amine is reacted with cyano acetic acid in the presence of $\mathrm{EDC} . \mathrm{HCl}$ in dichloromethane to give cyano acetamide derivative, which on reaction with carbon disulfide in the presence of base followed by methyl iodide to yield ketene dithiocyanoacetyl derivatives. Ketene dithiocyanoacetal derivatives cyclized with hydrazine hydrate to give amino pyrazole derivative. Different amino pyrazole derivatives is reacted with different ketene dithioacetyl derivatives to yield different pyrazolo [1,5a]pyrimidine derivatives.

Biological: All the synthesized compounds were screened against varieties of bacterial strains such Bacillus megaterium, Staphylococcus aureus, Escherichia coli, Pseudomonas aeruginosa, Aspergillus niger and Aspergillus flavus strains at minimal inhibitory concentration (MIC). Standard drugs like Streptomycin, Ampicillin and Nystatin were used for the comparison purpose. Compounds 8a, 8d and 8e are broad spectrum drug which can inhibit the growth of gram positive, gram negative bacteria and fungi. Among these compounds compound 8a is more potent. Compound 8g showed good activity against Escherichia coli, moderate activity against Bacillus megaterium \& Pseudomonas aeruginosa and poor activity against Staphylococcus aureus. Compound $\mathbf{8 h}$ displayed moderate activity against Bacillus megaterium, Staphylococcus aureus and Escherichia coli, while poor activity against Pseudomonas aeruginosa. Compound 8i showed moderate activity against Staphylococcus aureus \& Escherichia coli and poor activity against Bacillus megaterium \& Pseudomonas aeruginosa. Compound $\mathbf{8 j}$ displayed food activity against Pseudomonas aeruginosa and moderate activity against other strains. Compound 81 showed good activity against Pseudomonas aeruginosa and moderate activity against Staphylococcus aureus \& Escherichia coli and poor activity against Bacillus megaterium, while other showed moderate to poor activity.

Minimal fungicidal activity showed that compound $\mathbf{8 e}$ and $\mathbf{8 1}$ displayed good activity against Aspergillus niger and Aspergillus flavus while compound $\mathbf{8 d}$ and $\mathbf{8 g}$ showed moderate activity against the same. Compound 8a showed good activity against Aspergillus niger and moderate activity against Aspergillus flavus. Compound $\mathbf{8 f}$ and $\mathbf{8 h}$ displayed moderate activity against Aspergillus flavus Compound, while remaining all possessed poor activity against all fungal stains.

\section{CONCLUSION}

An efficient method for preparing substituted pyrazolo [1,5-a]pyrimidine derivatives was described and the structure of synthesized compounds was determine by IR, ${ }^{1} \mathrm{H}$ NMR, and Mass spectroscopic analysis and evaluated for their in vitro antimicrobial activity by broth dilution method which shows good to poor activity against different bacterial strains.

\section{Acknowledgement}

The authors are thankful to UGC for financial support under the scheme of innovative PG Program and also to Atmiya in-vitro Testing Laboratory, Yogidham, Kalawad Road, Rajkot for antimicrobial activity studies. 
Representative Spectra:

${ }^{1} \mathrm{H}$ NMR (DMSO-d ${ }^{6}$ ) spectra of compound 8f

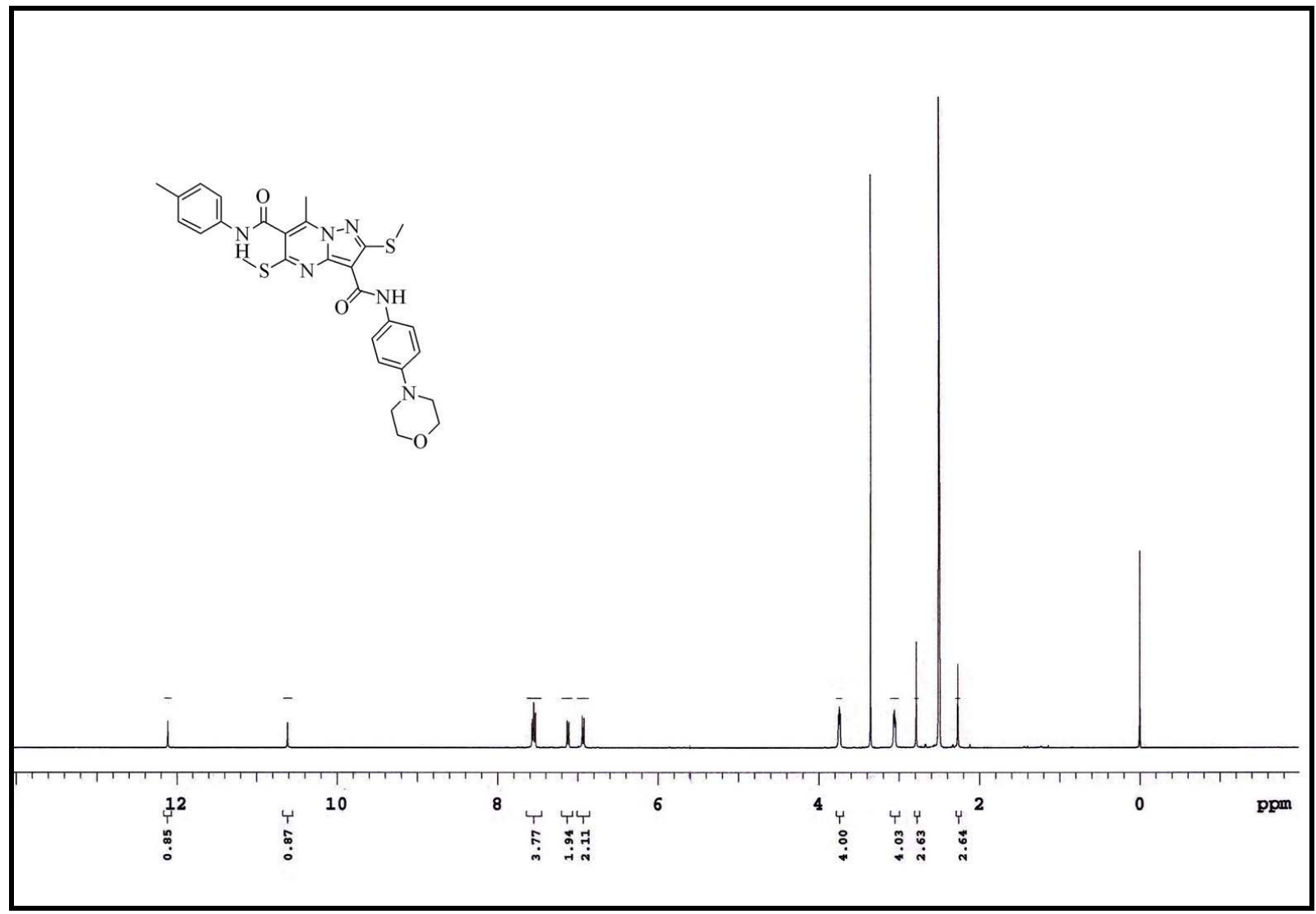

Fig. 2a

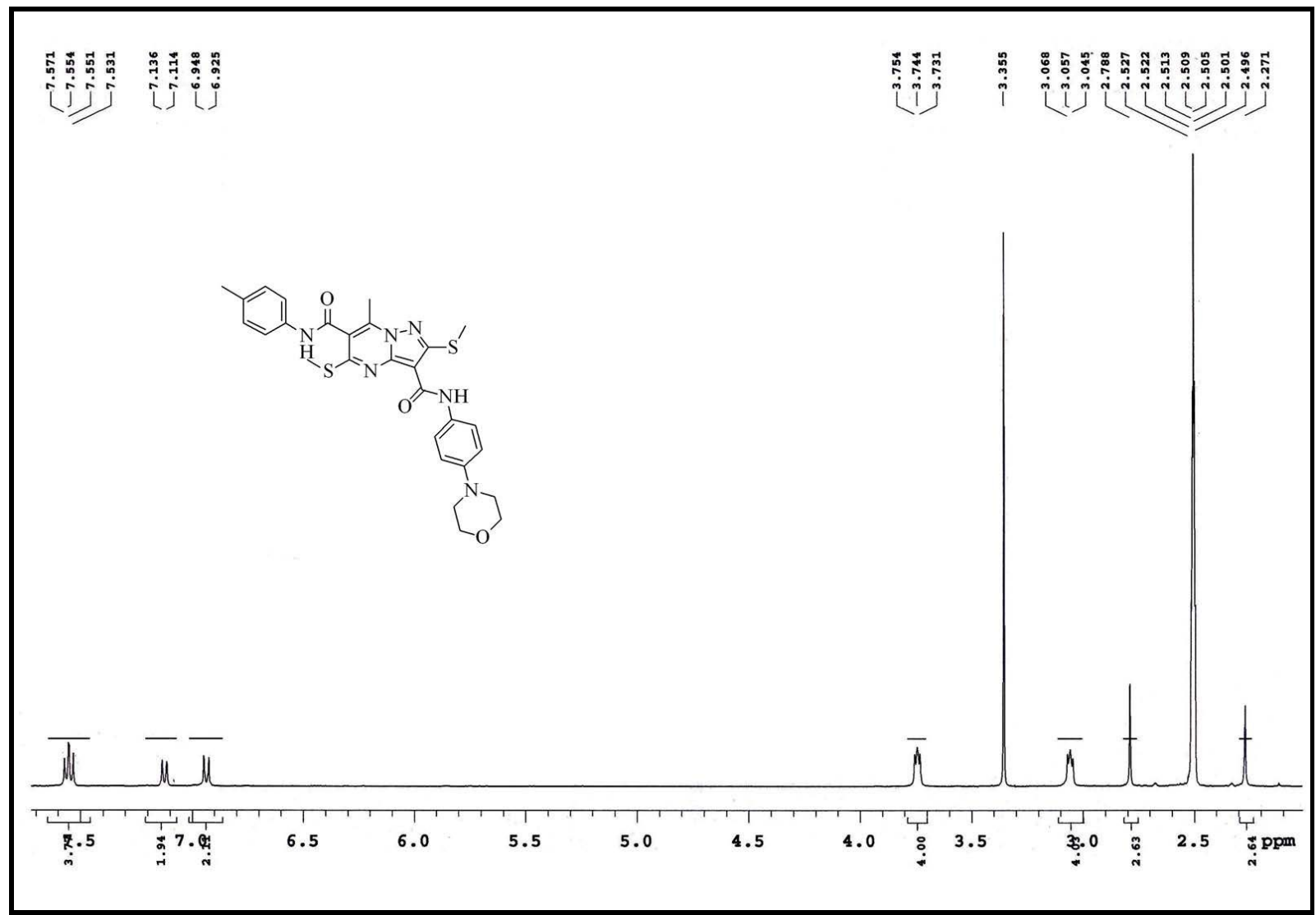

Fig. 2b 


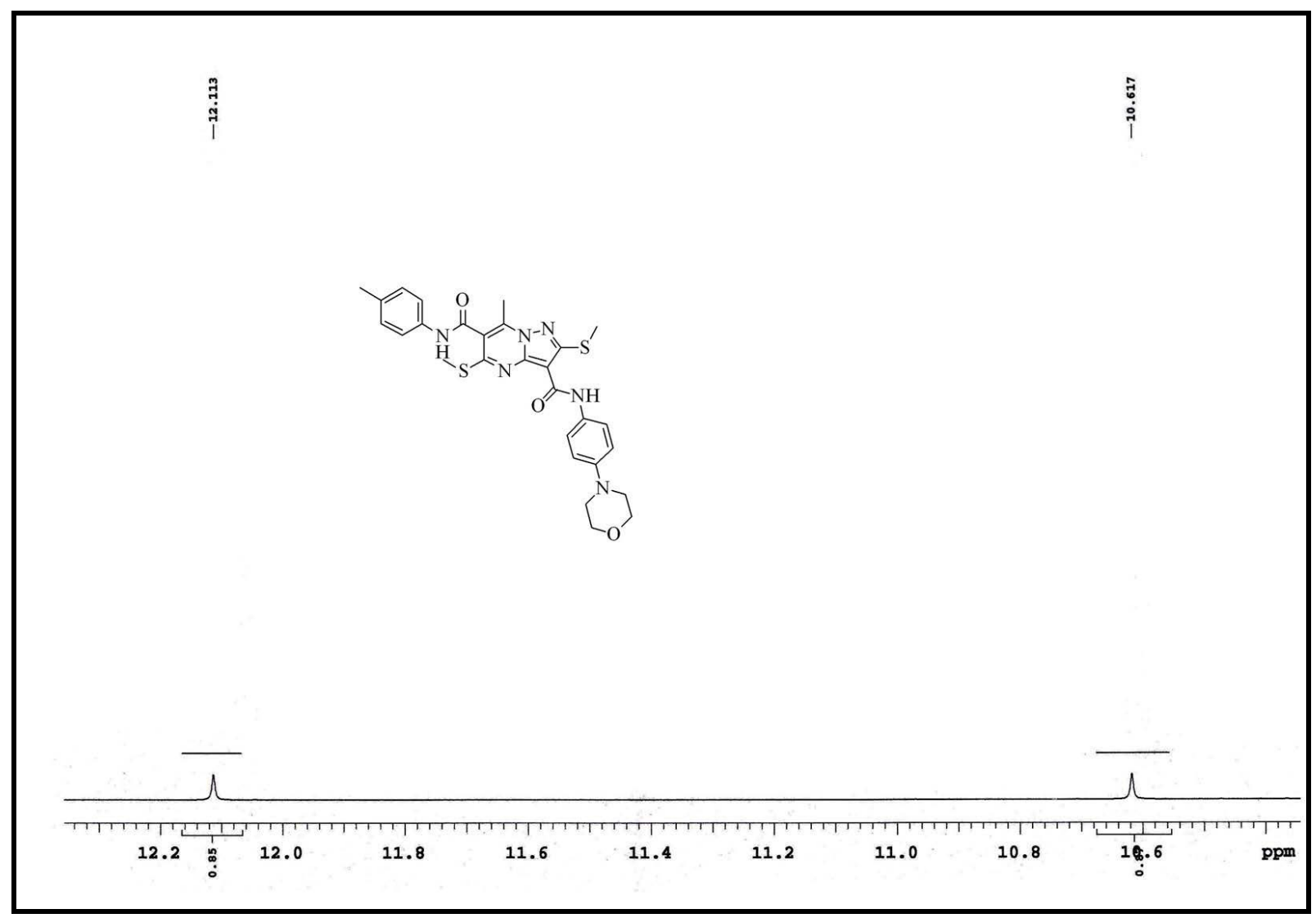

Fig. 2c

${ }^{1} \mathrm{H}$ NMR (DMSO-d ${ }^{6}$ ) spectra of compound 8i

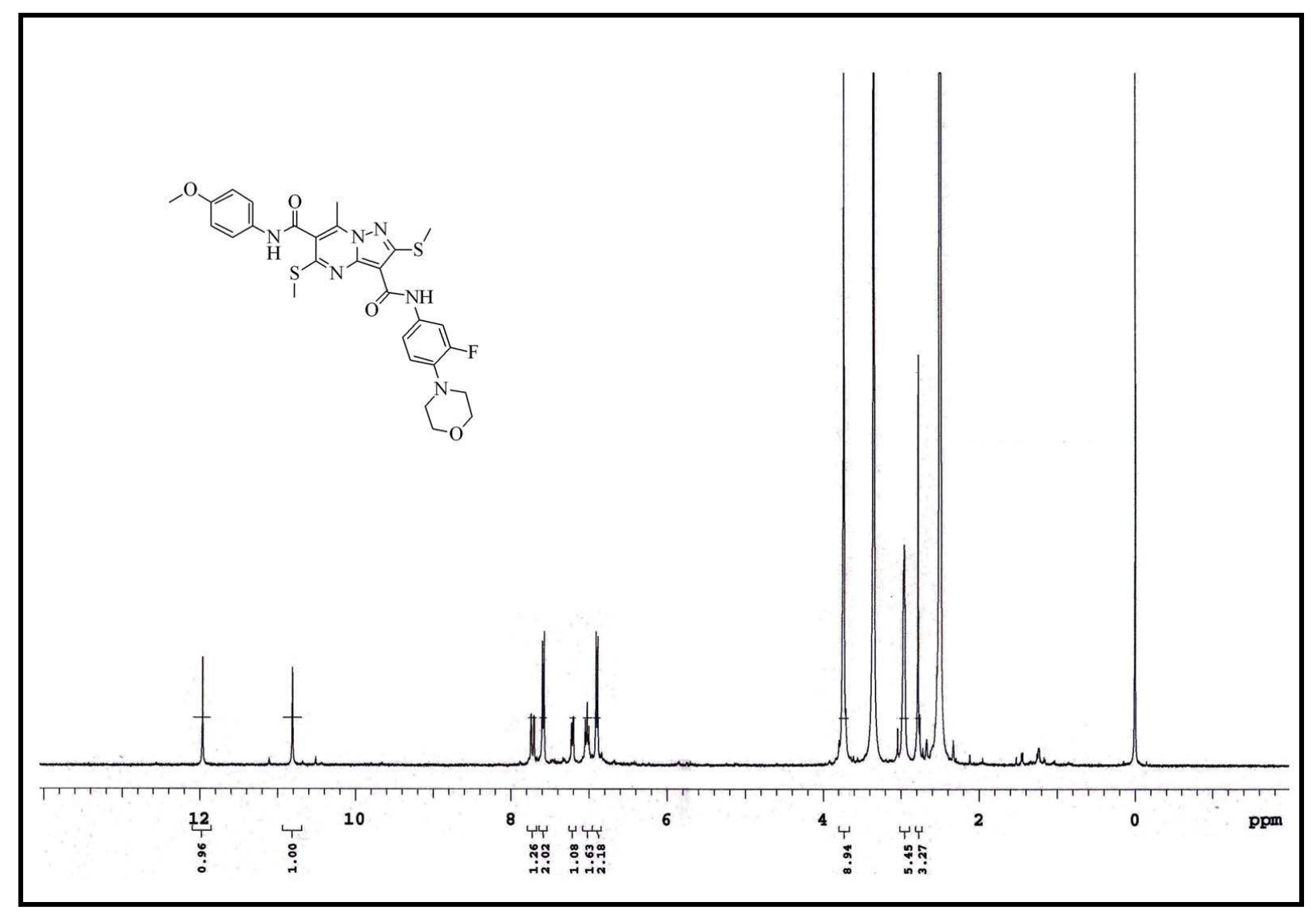

Fig. 3a 


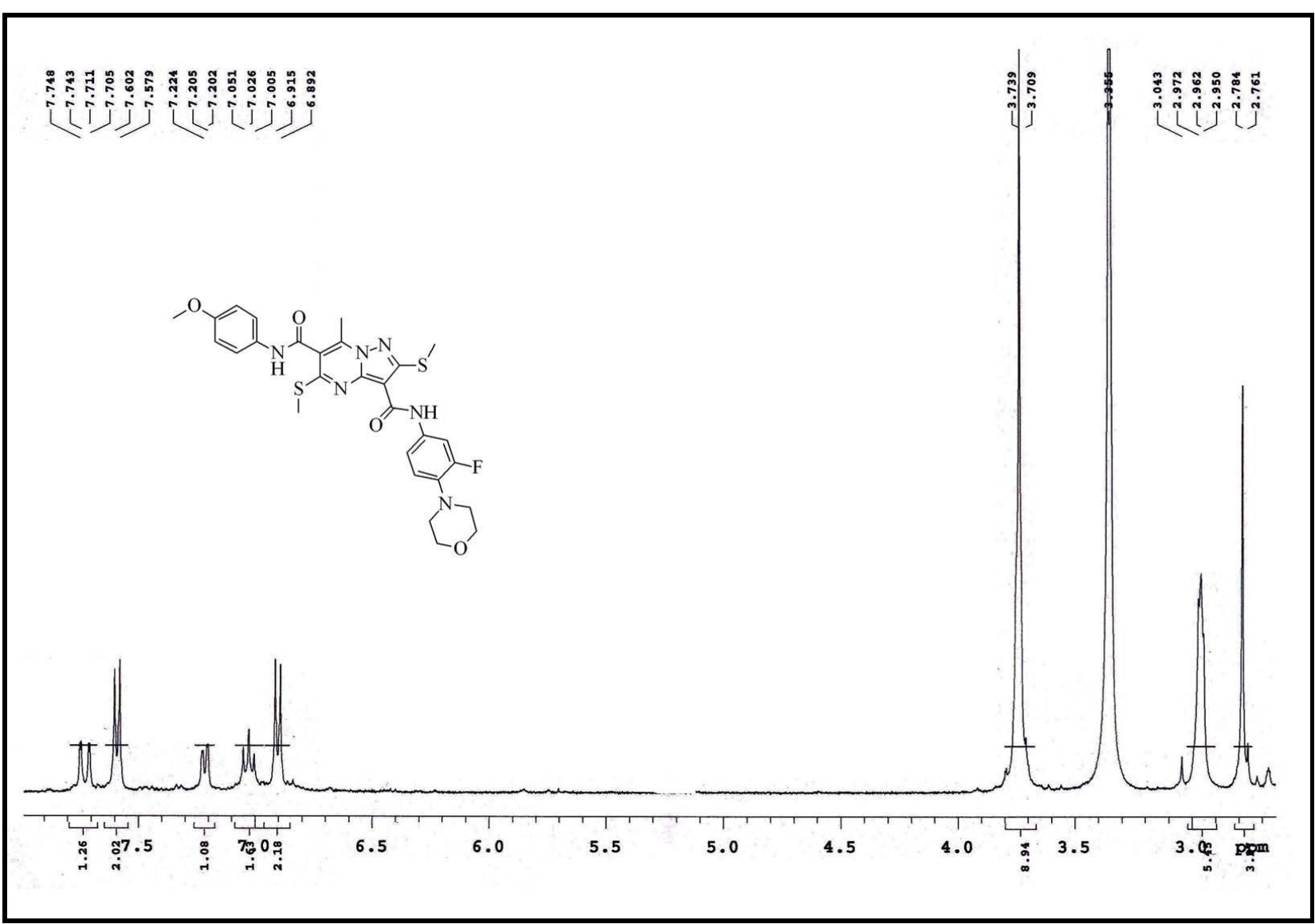

Fig. 3b

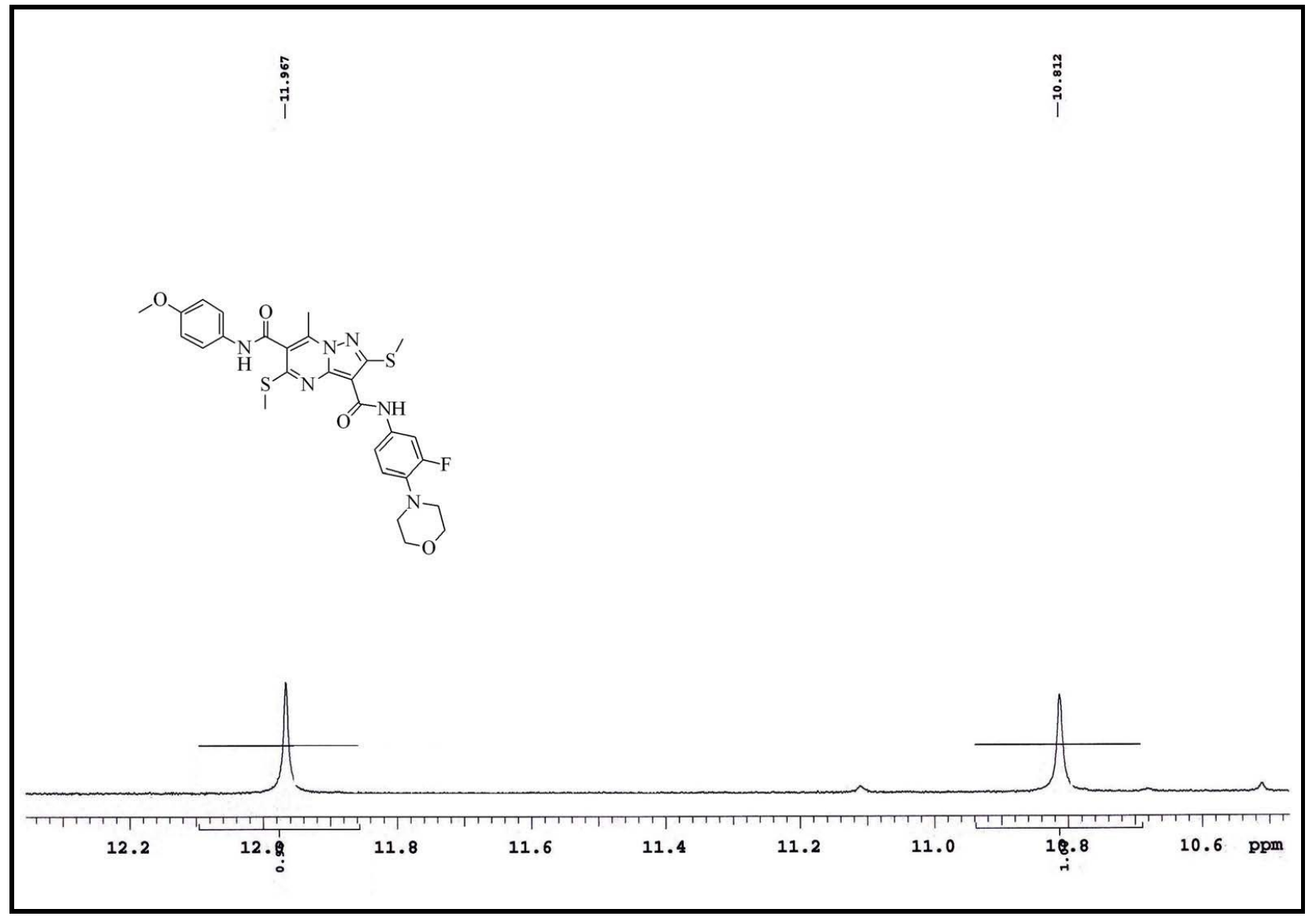

Fig. 3c 
${ }^{1}$ H NMR (DMSO-d ${ }^{6}$ ) spectra of compound 81

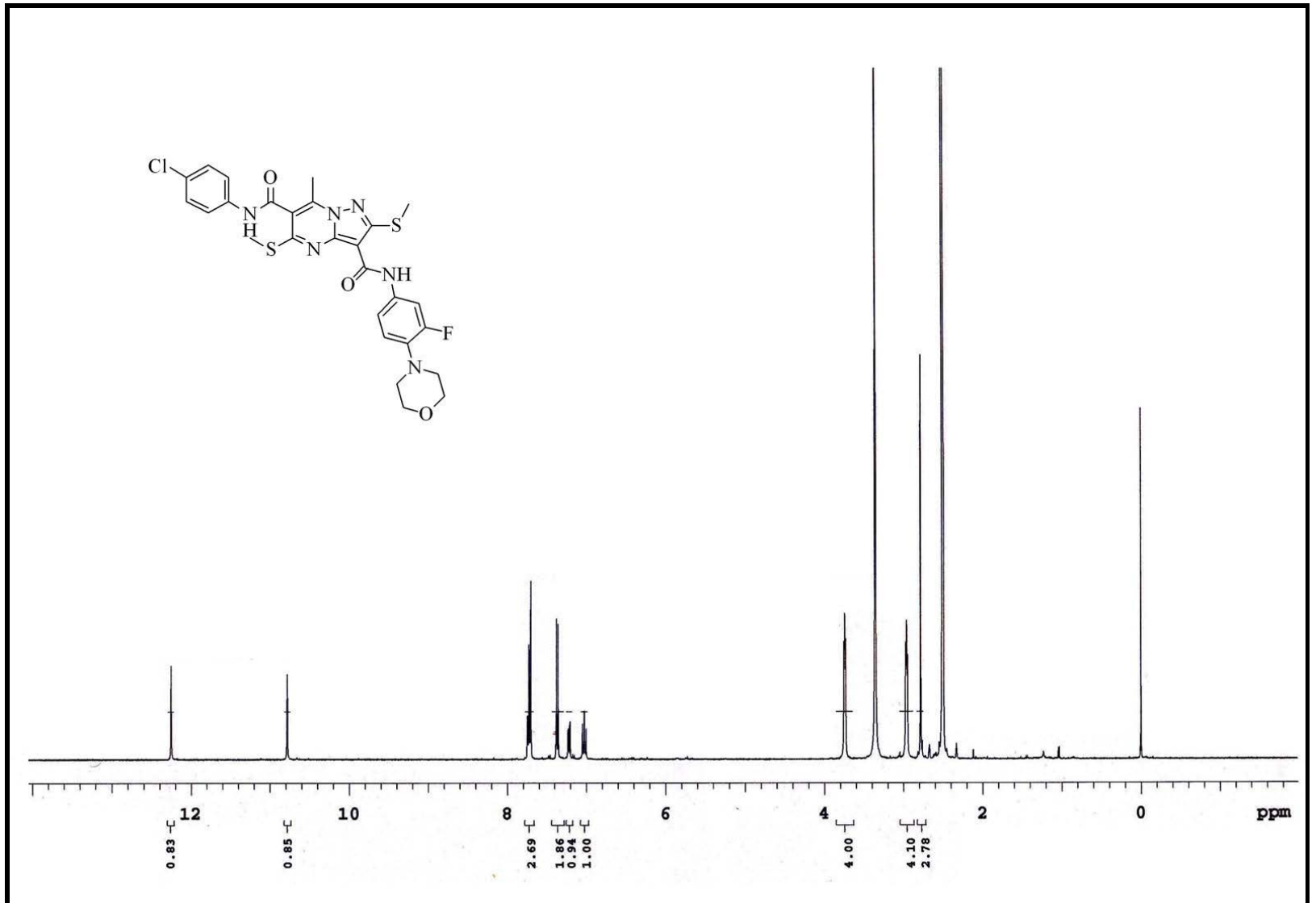

Fig. 4a

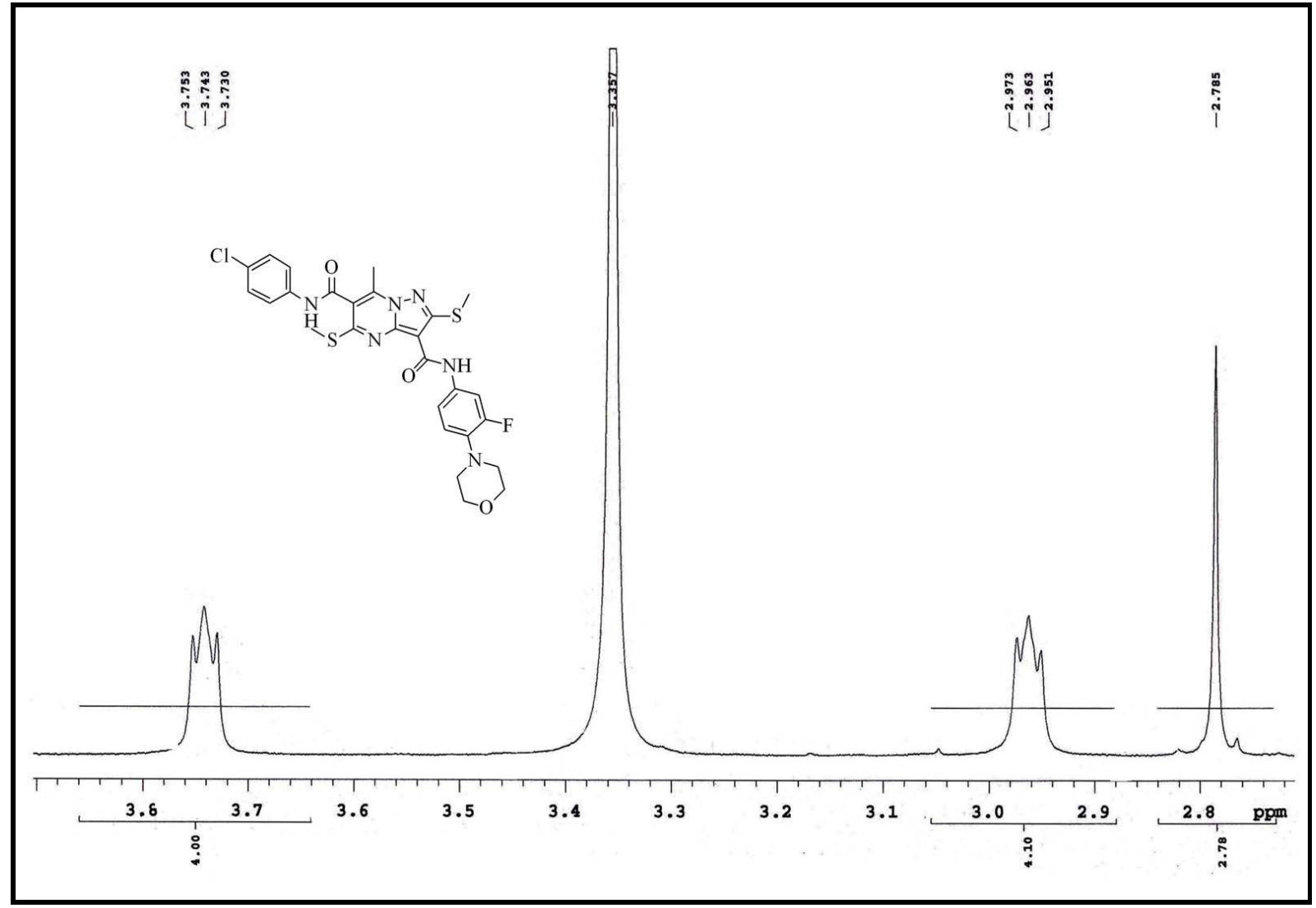

Fig. 4b 


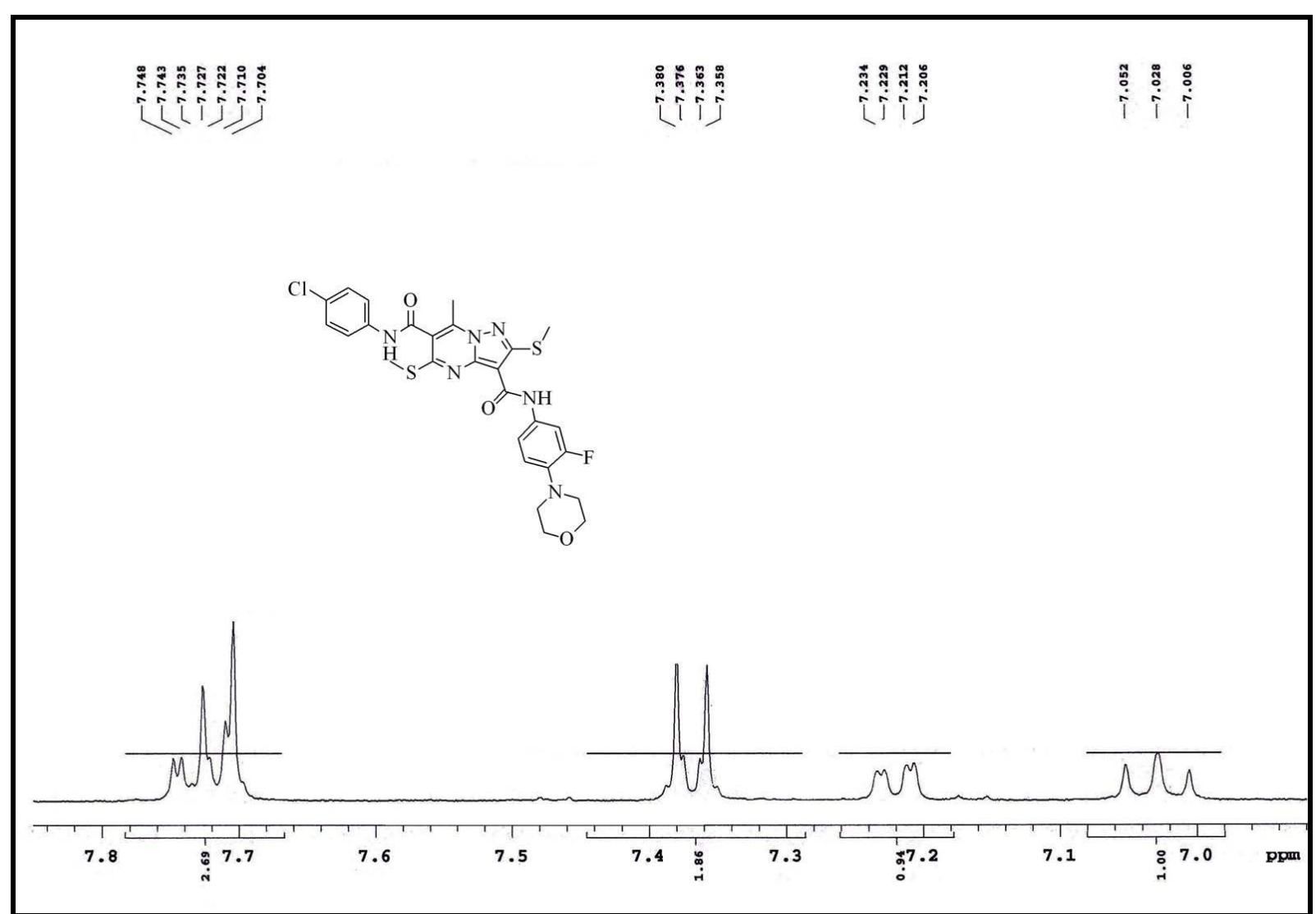

Fig. 4c

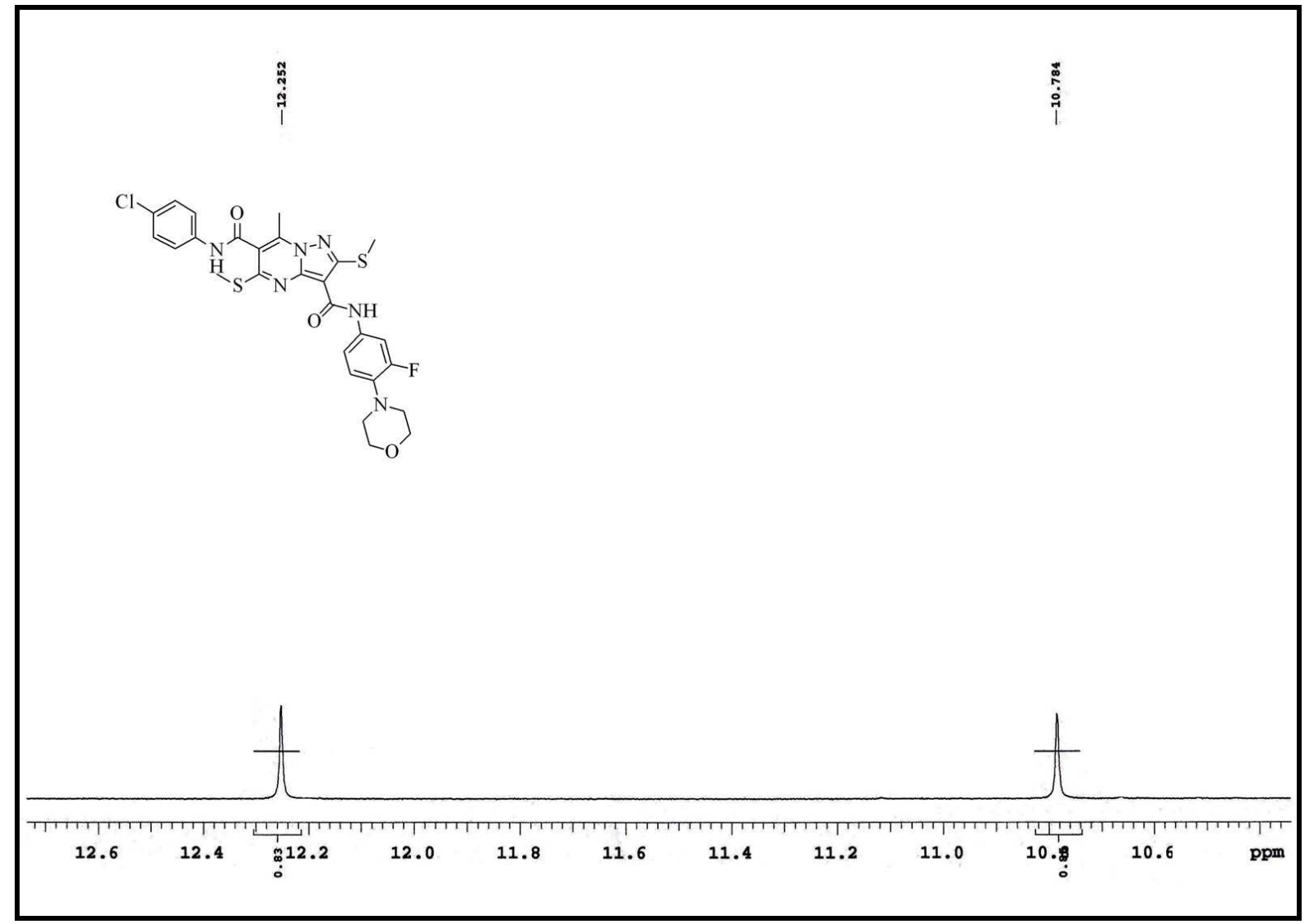

Fig. 4d 


\section{Appendix:}

Table 3: Structure of synthesized NCEs:

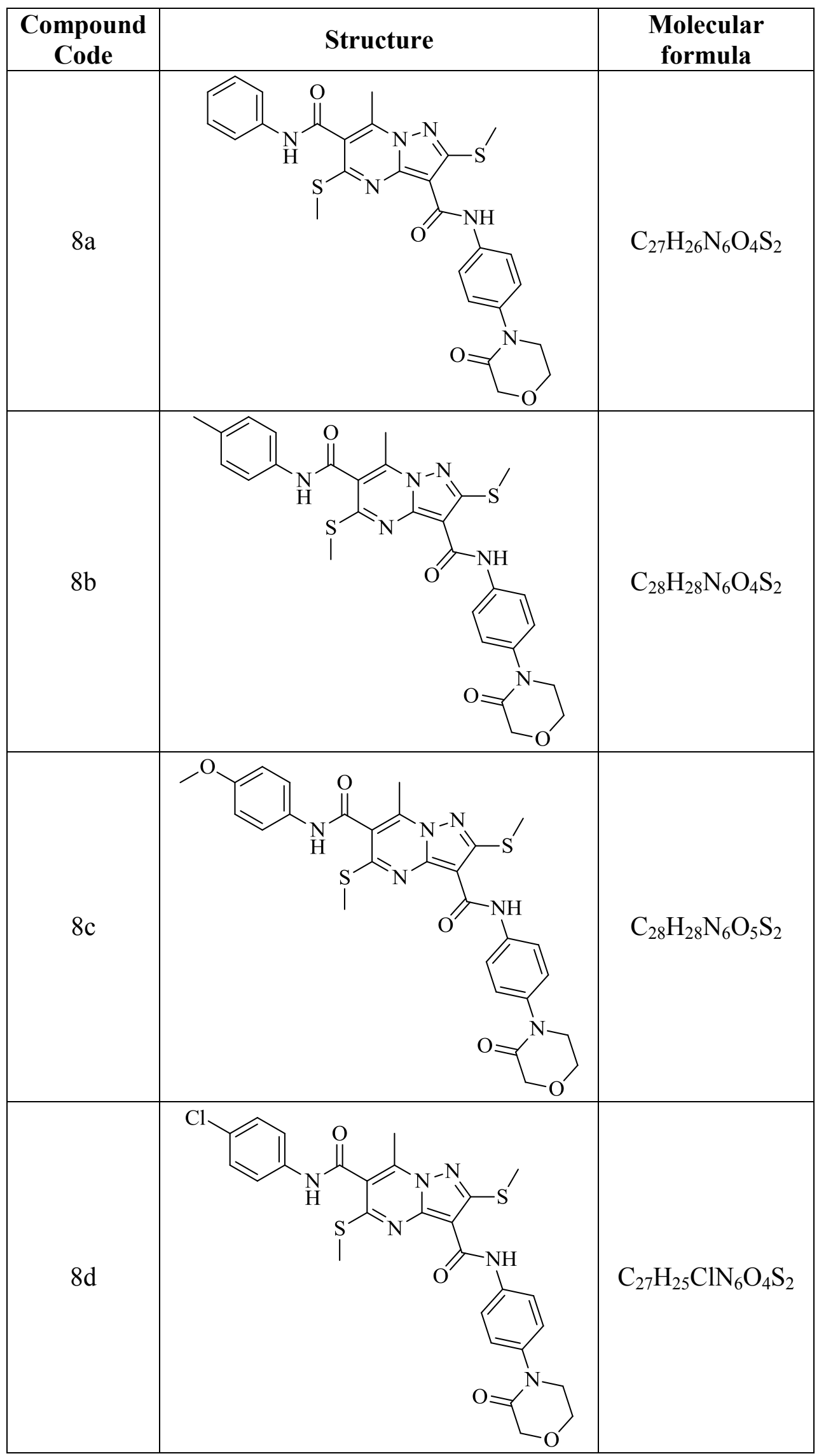




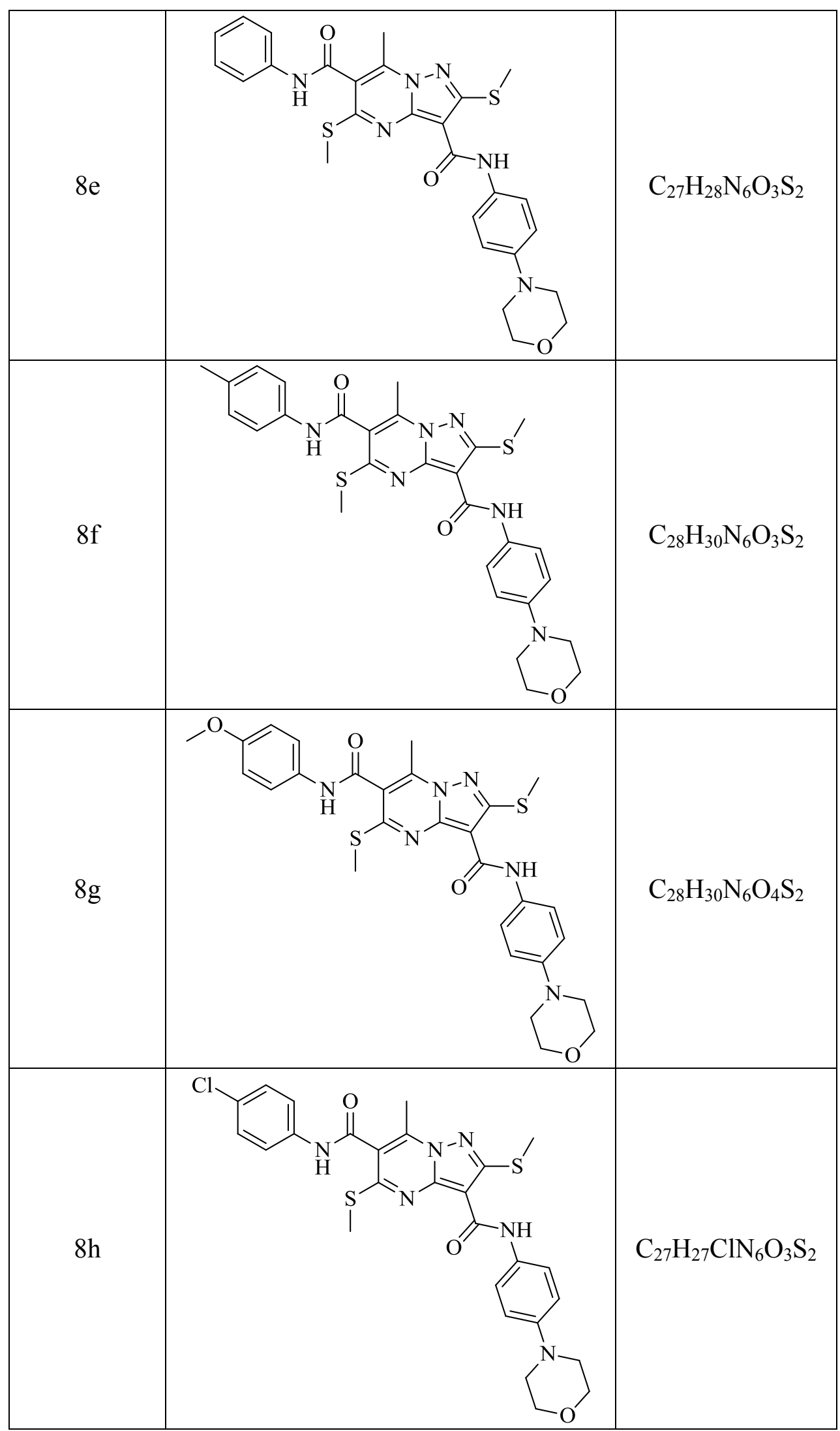




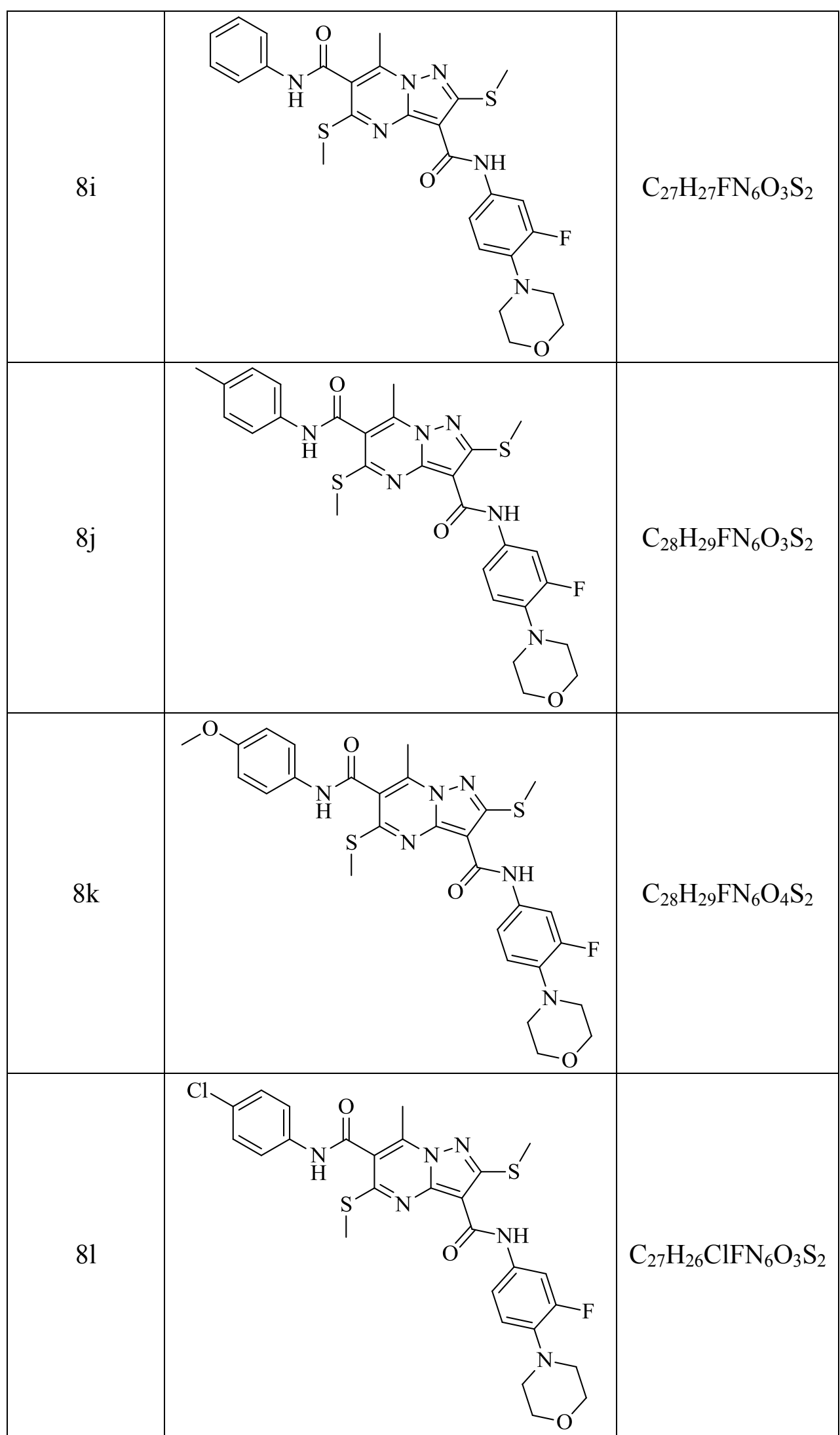




\section{References}

[1] D. Pansuriya, K. Menpara, N. Kachhadiya, J. Menpara, and K. Ladva, "Synthesis, Characterization \& Biological evaluation of sulfonamide analogue of Tetrazolo[1,5-a] pyrimidines," J. Appl. Chem., vol. 3, no. 6, pp. 2335-2342, 2014.

[2] J. A. ALEXANDER, G. P. WHEELER, D. D. HILL, and H. P. MORRIS, "EFFECTS OF 4HYDROXYPYRAZOL0(3,4-d)PYRIMIDINE UPON THE CATABOLISM OF PURINES BY VARIOUS TISSUES OF THE RAT AND UPON THE RATE OF GROWTH OF MORRIS 5123-C HEPATOMA,”Biochem. Pharmacol., vol. 15, pp. 881-889, 1966.

[3] B. Elion, S. Callahan, H. Nathan, S. Biebek, R. W. Rundles, and G. H. Hikhings, "POTENTIATION BY INHIBITION OF DRUG DEGRADATION: 6-SUBSTITUTED PURINES AND XANTHTNE OXIDASE,” Biochem. Pharmacol., vol. 12, pp. 85-93, 1963.

[4] R. A. Earl, R. J. Pugmire, G. R. Revankar, and eroy B. Townsend, "A Chemical and Carbon- 13 Nuclear Magnetic Resonance Reinvestigation of the N-Methyl Isomers Obtained by Direct Methylation of 5-Amino-3,4- dicyanopyrazole and the Synthesis of Certain Pyrazolo[ 3,4-d]pyrimidines," J. Org. Chem., vol. 40, no. 12, pp. 1822-1828, 1975.

[5] T. Novinson, B. Bhooshan, T. Okabe, G. R. Revankar, R. K. Robins, K. Senga, and H. R. Wilson, "Novel Heterocyclic Nitrofurfural Hydrazones. In Vivo Antitrypanosomal Activity," J. Med. Chem., vol. 19, no. 4, pp. 512-516, 1976.

[6] K. Senga, T. Novinson, H. R. Wilson, and R. K. Robins, "Synthesis and Antischistosomal Activity of Certain Pyrazolo[ 1,5-a]pyrimidines," J. Med. Chem., vol. 24, pp. 610-613, 1981.

[7] M. Suzuki, H. Iwasaki, Y. Fujikawa, M. Sakashita, M. Kitaharac, and R. Sakoda, "Synthesis and Biological Evaluations of Condensed Pyridine and Condensed Pyrimidine-Based HMGCoA Reductase Inhibitors," Bioorg. Med. Chem. Lett., vol. 11, pp. 1285-1288, 2001.

[8] C. Almansa, A. F. de Arriba, F. L. Cavalcanti, L. A. Gomez, A. Miralles, M. Merlos, J. Garcin-Rafanell, and J. Forn, "Synthesis and SAR of a New Series of COX-2-Selective Inhibitors : Pyrazolo [ 1 , 5- a ] pyrimidines," J. Med. Chem., vol. 44, pp. 350-361, 2001.

[9] T. Novinson, R. Hanson, M. K. Dimmitt, L. N. Simon, R. K. Robins, and D. E. O’Brien, “3Substituted 5,7-Dimethylpyrazolo[ 1,5-a]pyrimidines, 3',5'-Cyclic-AMP Phosphodiesterase Inhibitors," J. Med. Chem., vol. 17, no. 6, pp. 645-648, 1974.

[10] C. Chen, K. M. Wilcoxen, C. Q. Huang, Y. Xie, J. R. Mccarthy, T. R. Webb, Y. Zhu, J. Saunders, X. Liu, T. Chen, H. Bozigian, and D. E. Grigoriadis, "Design of 2,5-Dimethyl-3(6-dimethyl-4-methylpyridin-3-yl)-7-dipropylamino- pyrazolo[1,5-a]pyrimidine (NBI 30775/R121919) and Structure-Activity Relationships of a Series of Potent and Orally Active Corticotropin-Releasing Factor Receptor Antagonists," J. Med. Chem., vol. 47, pp. 4787-4798, 2004.

[11] C. Q. Huang, K. M. Wilcoxen, D. E. Grigoriadis, J. R. Mccarthy, and C. Chen, "Design and synthesis of 3- ( 2-pyridyl ) pyrazolo [ 1, 5- a ] pyrimidines as potent CRF 1 receptor antagonists," Bioorg. Med. Chem. Lett., vol. 14, pp. 3943-3947, 2004.

[12] C. Chen, K. M. Wilcoxen, C. Q. Huang, J. R. Mccarthy, T. Chen, and D. E. Grigoriadis, "Optimization of 3-phenylpyrazolo [ 1,5- a ] pyrimidines as potent corticotropin-releasing factor-1 antagonists with adequate lipophilicity and water solubility," Bioorg. Med. Chem. Lett., vol. 14, pp. 3669-3673, 2004.

[13] D. J. Wustrow, T. Capiris, R. Rubin, J. A. Knobelsdorf, H. Akunne, M. D. Davis, R. Mackenzie, T. A. Pugsley, K. T. Zoski, T. G. Heffner, and L. D. Wise, "PYRAZOLO[1,5a]PYRIMIDINE CRF-1 RECEPTOR ANTAGONISTS," Bioorg. Med. Chem. Lett., vol. 8, pp. 2067-2070, 1998.

[14] S. Selleri, P. Gratteri, C. Costagli, C. Bonaccini, A. Costanzo, F. Melani, G. Guerrini, G. Ciciani, B. Costa, F. Spinetti, and F. Bruni, "Insight into 2-phenylpyrazolo[1,5-a]pyrimidin3-yl acetamides as peripheral benzodiazepine receptor ligands: Synthesis, biological evaluation and 3D-QSAR investigation," Bioorg. Med. Chem., vol. 13, pp. 4821-4834, 2005 . 
[15] S. Selleri, F. Bruni, C. Costagli, A. Costanzo, G. Guerrini, G. Ciciani, and C. Martini, “2Arylpyrazolo [ 1 , 5- a ] pyrimidin-3-yl Acetamides . New Potent and Selective Peripheral Benzodiazepine Receptor Ligands," Bioorg. Med. Chem., vol. 9, pp. 2661-2671, 2001.

[16] S. Selleri, F. Bruni, C. Costagli, A. Costanzo, G. Guerrini, G. Ciciani, and C. Martini, "Synthesis and BZR Affnity of Pyrazolo [ 1, 5- a ] pyrimidine Derivatives . Part 1: Study of the Structural Features for BZR Recognition," Bioorg. Med. Chem., vol. 7, pp. 2705-2711, 1999.

[17] I. Drizin, M. W. Holladay, L. Yi, H. Q. Zhang, S. Gopalakrishnan, M. Gopalakrishnan, K. L. Whiteaker, S. A. Buckner, J. P. Sullivan, and W. A. Carroll, "Structure - Activity Studies for a Novel Series of Tricyclic Dihydropyrimidines as K ATP Channel Openers ( KCOs )," Bioorg. Med. Chem. Lett., vol. 12, pp. 1481-1484, 2002.

[18] W. A. Foster and C. Jack, "US 256309," 1882.

[19] L. J. Phillipson, D. H. Segal, T. L. Nero, M. W. Parker, S. Wan, M. De Silva, M. A. Guthridge, A. H. Wei, and C. J. Burns, "Discovery and SAR of novel pyrazolo[1,5a]pyrimidines as inhibitors of CDK9," Bioorg. Med. Chem., vol. 23, no. 19, pp. 6280-6296, 2015.

[20] W. E. Kirkpatrick, T. Okabe, I. W. Hillyard, R. K. Robins, A. T. Dren, and T. Novinson, “3Halo-5,7-dimethylpyrazolo[ 1,5-a]pyrimidines, a Nonbenzodiazepinoid Class of Antianxiety Agents Devoid of Potentiation of Central Nervous System Depressant Effects of Ethanol or Barbiturates," J. Med. Chem., vol. 20, no. 3, pp. 386-393, 1977.

[21] C. F. P. George, "GABA receptors and mechanism of action of hypnotics," Lancet, vol. 358, pp. 1623-1626, 2001.

[22] S. K. Sullivan, R. E. Petroski, G. Verge, R. S. Gross, A. C. Foster, and D. E. Grigoriadis, "Characterization of the Interaction of Indiplon , a Novel Pyrazolopyrimidine SedativeHypnotic, with the GABA A Receptor," J. Pharmacol. Exp. Ther., vol. 311, no. 2, pp. 537546, 2004.

[23] F. Wegner, W. Deuther-conrad, M. Scheunemann, P. Brust, S. Fischer, A. Hiller, M. Diekers, K. Strecker, K. Wohlfarth, C. Allgaier, J. Steinbach, and A. Hoepping, "GABA A receptor pharmacology of fluorinated derivatives of the novel sedative-hypnotic pyrazolopyrimidine indiplon," Eur. J. Pharmacol., vol. 580, pp. 1-11, 2008.

[24] A. Hoepping, M. Diekers, W. Deuther-conrad, M. Scheunemann, S. Fischer, A. Hiller, F. Wegner, J. Steinbach, and P. Brust, "Synthesis of fluorine substituted pyrazolopyrimidines as potential leads for the development of PET-imaging agents for the GABA A receptors," Bioorg. Med. Chem., vol. 16, pp. 1184-1194, 2008.

[25] A. Lippa, P. Czobor, J. Stark, B. Beer, E. Kostakis, M. Gravielle, S. Bandyopadhyay, S. J. Russek, T. T. Gibbs, D. H. Farb, and P. Skolnick, "Selective anxiolysis produced by ocinaplon , a GABA A receptor modulator," PNAS, vol. 102, no. 20, pp. 7380-7385, 2005.

[26] N. R. Mirza, R. J. Rodgers, and L. S. Mathiasen, "Comparative Cue Generalization Profiles of L-838, 417 , Zopiclone, and Various Benzodiazepines in Chlordiazepoxide and Zolpidem Drug Discrimination," J. Pharmacol. Exp. Ther., vol. 316, no. 3, pp. 1291-1299, 2006. 